\title{
Potensi Pengembangan Wisata Berbasis Masyarakat Di Desa Banyuanyar, Boyolali
}

\author{
Hafni Khairunnisa ${ }^{\mathrm{a}, 1, *}$, Trias Shofi Nur’aini ${ }^{\mathrm{b}, 2}$ \\ ${ }^{a}$ Fakultas Syariah dan Ekonomi Islam, IAIN Syekh Nurjati, Kota Cirebon, 45132 Jawa Barat, Indonesia. Telp. (0231) \\ 481264. Faks (0231)489926 \\ ${ }^{b}$ Fakultas Dakwah, IAIN Salatiga, Kota Salatiga, 50716, Jawa Tengah, Indonesia. \\ ${ }^{1}$ Hafni.k@gmail.com*; ${ }^{2}$ triasshofi97@gmail.com; \\ * Corresponding author
}

ARTICLE INFO

Article history:

Submitted: May 22, 2020

Reviewed: June 9, 2020

Accepted: June 18, 2020

Published: June 30, 2020

Keyword: Development Community. Tourism Village, Community Based Tourism.

Kata kunci: Pengembangan Masyarakat. Desa Wisata, Pariwisata Berbasis Masyarakat.

\section{ABSTRACT}

This study aims to find out how potentially Banyuanyar Village to developed into tourism village. Tourism village is form of implementation community based tourism. A purpose from community based tourism is to encouraged local community so they can be more prosperous. A village can be developed as well to be tourism village if fullfill several criteria tourism development. They are "potential product or potential attraction in destination", "local community", "potential of local human resources", "availability of facilities and infrastructure", and "ability to create a tourism market". Based from thos criteria, Banyuanyar village has enough potential to be developed as a tourism village. A strong aspect are found on the tourist attraction. Currently Banyuanyar Village has been visited by tourists but is still limited to the coffee segment. The weakness that still needs to be improved is the ability to create markets. Banyuanyar village is currently still having difficulties in making tour packages, and to determine the right market segment and the right marketing strategy.

\begin{abstract}
ABSTRAK
Penelitian ini bertujuan untuk mengetahui seberapa besar potensi yang dimiliki oleh Desa Banyuanyar untuk dikembangkan menjadi desa wisata. Desa wisata adalah salah satu bentuk implementasi pengembangan wisata berbasis masyarakat. Harapan dari pemberdayaan masyarakat melalaui kegiatan wisata adalah masyarakat dapat lebih sejahtera. Dalam pengembangan desa wisata terdapat beberapa kriteria pengembangan yang harus diperhatikan yaitu "potensi produk atau potensi atraksi pada destinasi", "komunitas masyarakat", "potensi SDM lokal", "ketersediaan fasilitas dan sarana - prasarana" serta "kemampuan dalam menciptakan pasar wisatawan". Dari kelima kriteria pengembangan desa wisata tersebut, Desa Banyuanyar cukup memiliki potensi untuk dikembangkan sebagai desa wisata. Aspek yang cukup kuat terdapat pada aspek daya tarik wisata. Saat ini Desa Banyunanyar sudah mendapat kunjungan wisatawan tetapi masih sebatas pada segmen kopi. Kekurangan yang masih harus dibenahi adalah kemampuan dalam menciptakan pasar. Desa Banyuanyar saat ini masih kesulitan dalam pembuatan paket wisata, menentukan segmen pasar yang tepat dan strategi pemasaran yang tepat.
\end{abstract}

Copyright @ 2019 Politeknik Negeri Samarinda. All rights reserved.

$\mathrm{W}$ : http://e-journal.polnes.ac.id/index.php/edutourism/

E : Jurnal_edutourism@polnes.ac.id 


\section{Pendahuluan}

Indonesia adalah negara yang mempunyai potensi dan kekayaan alam yang melimpah. Potensi dan kekayaan alam ini terbagi menjadi kekayaan yang terkandung di dalam tanah (Mineral, Gas, Emas, Tembaga, Perak, Minyak bumi), kekayaan yang berupa potensi udara (oksigen, hidrogen, nitrogen, oksida nitrous dan argon yang diperoleh melalui penguraian udara secara kimiawi). Kekayaan berikutnya merupakan kekayaan yang terdapat di atas tanah (hewan, tumbuhan, air, dan lain-lain), kekayaan yang berada di dalam lautan (ikan, terumbu karang, garam, dan lain-lain. Potensi alam yang melimpah ini tentunya merupakan sebuah keunggulan bagi bangsa Indonesia dan dapat dipergunakan untuk pemberdayaan masyarakat dan sebesar-besarnya kesejahteraan masyarakat lokal.

Pemberdayaan masyarakat merupakan upaya untuk meningkatkan perekonomian masyarakat melalui sumber daya atau potensi yang berada di sekitar masyarakat tanpa niatan untuk merusak ekosistem dan kekayaan alam (Hadiwijoyo, 2012), (Demartoto, 2009), (Brohman, 1996); (Nuryanti, 2015). Indonesia merupakan negara kepulauan yang memiliki banyak pulau. Pulau Jawa merupakan salah satu pulau di Indonesia dan merupakan pulau terpadat. Pulau Jawa sendiri terdiri dari Provinsi Banten, Provinsi DKI Jakarta, Provinsi Jawa Barat, Provinsi Jawa Tengah, Provinsi DI Yogyakarta, Provinsi Jawa Timur. Di wilayah Provinsi Jawa Tengah dengan ibukota di Semarang, memiliki beberapa Kabupaten dan Kota, salah satunya Kabupaten Boyolali. Kabupaten boyolali terletak sekitar $25 \mathrm{~km}$ sebelah barat Kota Surakarta, Kabupaten Boyolali memiliki 14 Kecamatan.

Mayoritas penduduk di

Kabupaten Boyolali merupakan masyarakat pedesaan. Hal ini dikarenakan karena kondisi alam yang mayoritas desa dan desa. Kabupaten Boyolali mayoritas beriklim sejuk karena berada di lereng Gunung Merapi dan Gunung Merbabu. Salah satu Kecamatan di Kabupaten Boyolali yaitu Kecamatan
Ampel. Di Kecamatan Ampel ada sebuah desa yaitu Desa Banyuanyar.

Sejalan dengan naiknya trend pengembangan pariwisata berbasis masyarakat yang sesuai dengan hakikat pemberdayaan masyarakat untuk menciptakan masyarakat yang tangguh dan berdaya guna. Maka penelitian ini akan mencoba mengkaji potensi yang dimiliki oleh Desa Banyuanyar untuk dapat dikembangkan sebagai salah satu daerah wisata berdasarkan dengan kriteria pengembangan desa wisata.

\section{Tinjauan Pustaka}

\section{A. Pariwisata}

Pariwisata berkembang karena pergerakan manusia dalam mencari sesuatu yang baru, untuk mencari suasana yang baru atau untuk mendapat pengalaman baru (Pitana dan Gayatri, 2005). Pariwisata dapat diartikan sebagai perjalanan dari daerah asal menuju tempat lain yang memakan waktu lebih dari 24 jam dan dengan tujuan untuk bersenang-senang dan tidak menghasilkan uang (Yoeti : 2008). Dapat disimpulkan bahwa unsur utama pariwisata adalah adanya unsur pergerakan atau perjalanan dari satu tempat ke tempat yang lain; tinggal sementara untuk beberapa saat yang bukan merupakan tempat tinggalnya; dan tujuan utama dari perjalanan tersebut bukan untuk mendapat penghasilan.

Pariwisata merupakan berbagai macam kegiatan wisata dan didukung berbagai fasilitas serta pelayanan yang disediakan oleh masyarakat, pengusaha, pemerintah daerah dan pengusaha (Direktorat Pemberdayaan Masyarakat : 2013). Demartoto (2009) mendefinisikan pariwisata sebagai suatu gejala yang sangat kompleks, yang menyangkut manusia seutuhnya dan memiliki berbagai aspek seperti aspek sosiologis, psikologis, ekonomis, ekologis dan sebagainya. Aspek yang biasa lebih dominan dalam dunia pariwisata adalah aspek ekonomi.

WTO menyatakan bahwa dalam pembangunan pariwisata, kini lebih 
condong ke arah pembangunan pariwisata berkelanjutan. Pembangunan pariwisata berkelanjutan bukan hanya melihat pariwisata dari sisi ekonomi tetapi juga melihat dari sisi lingkungan, sosial dan teknologi (Direktorat Pemberdayaan Masyarakat, 2013). Dalam konsep pariwisata berkelanjutan pengembangan kegiatan pariwisata berbasis masyarakat merupakan sebuah kerangka yang penting. Hal ini dikarenakan masyarakat merupakan pelaku utama baik dalam pengelolaan lingkungan, pengelolaan budaya yang masuk ke dalam ranah sosial, teknologi dan merupakan pelaku dari aktivitas ekonomi.

\section{B. Pemberdayaan Masyarakat Melalui Pariwisata}

Pemberdayaan masyarakat merupakan upaya untuk meningkatkan kesadaran, kapasitas, akses dan peran masyarakat, baik secara individu maupun kelompok, dalam memajukan kualitas hidup, kemandirian, dan kesejahteraan melalui kegiatan kepariwisataan (Direktorat Pemberdayaan Masyarakat : 2013). Pemberdayaan masyarakat merupakan upaya menjadikan masyarakat berdaya dan mandiri, mampu berdiri di atas kakinya sendiri. Pemberdayaan masyarakat pada dasarnya bertujuan untuk membawa perubahan pada perilaku masyarakat Perubahan ini adalah perubahan menuju ke arah yang lebih baik yang bertujuan untuk meningkatkan kualitas dan kesejahteraan hidup masyarakat secara bertahap (Anwas, 2013).

Wrihatnolo dan Dwidjowijoto dalam Astuti, dkk (2015) menyatakan bahwa proses pemberdayaan terbagi tiga proses pemberdayaan pertama, tahap penyadaran, target sasaran adalah masyarakat yang kurang mampu. Masyarakat disini harus dijelaskan bahwa mereka memiliki hak untuk menyelesaikan permasalahan hidup yang mereka alami dan keluar dari permasalahan itu.

Kedua, tahap pengembangan kapasitas, tahap ini terdiri dari tiga jenis yaitu, Pengembangan kapasitas $S D M$ yang bertujuan agar manusia dalam sebuah dapat memiliki keahlian dan kompetensi dan dapat dilakukan dengan pendidikan dan pelatihan. Pengembangan kapasitas organisasi dengan melakukan perbaikan pada sebuah organisasi. Pengembangan kapasitas sistem nilai dilakukan dengan membuat aturan yang harus dipatuhi oleh setiap anggota dalam organisasi.

Ketiga, tahap penyadaran pada tahap ini target sasaran diberikan sumber daya yang dapat digunakan untuk melakukan perubahan ke arah yang lebih baik. Target sasaran diberikan modal, alat, kekuasaan dan otoritas yang diperlukan untuk lebih dapat berdaya.

Konsep pemberdayaan mencakup pengertian community development (pembangunan masyarakat) dan communitybased development (pembangunan yang bertumpu pada masyarakat), dan tahap selanjutnya muncul istilah community-driven development yaitu sebagai pembangunan yang diarahkan masyarakat atau yang digerakkan oleh masyarakat (Wrihatnolo dan Nugroho : 2007).

Pemberdayaan masyarakat melalui kegiatan pariwisata nsecara ideal memiliki prinsip "dari masyarakat, oleh masyarakat dan untuk masyarakat" (Demartoto, 2009). Masyarakat dapat dilibatkan mulai dari proses perencanaan, pelaksana dan evaluasi. Masyarakat dilibatkan secara aktif dan berpartisipasi karena tujuan akhir adalah meningkatkan kesejahteraan dan kualitas hidup masyarakat.

Pemberdayaan masyarakat melalui pariwisata berbasis komunitas. Bentuk implementasi 
dari pariwisata berbasis komunitas dapat diwujudkan dalam sebuah desa wisata (Rogi, 2015). Desa wisata merupakan bentuk implementasi dari pemberdayaan masyarakat maelalui kegiatan pariwisata. Hal ini dikarenakan masyarakat desa akan menjadi pelaku utama. Masyarakat akan diberdayakan baik dari sisi sosial, ekonomi, budaya.

Kriteria yang harus dimiliki oleh setiap desa jika ingin dikembangkan sebagai desa wisata adalah (Direktorat Pemberdayaan Masyarakat, 2013) : a) potensi produk atau daya tarik yang unik dan khas, b) memiliki komunitas masyarakat yang siap dan mampu menerima wisatawan, c) SDM lokal desa yang mendukung kegiatan kepariwisataan, d) ketersediaan fasilitas dan sarana prasaranan yang memadai untuk kegiatan kepariwisataan, dan e) potensi dan kemampuan dalam menciptakan pasar wisatawan.

\section{Metodologi Penelitian}

Lokasi penelitian berlokasi di Desa Banyuanyar, Kecamatan Ampel, Kabupaten Boyolali, Jawa Tengah. Metode Penelitian yang digunakan adalah deskriptif kualitatif. Penelitian ini diharapkan mampu menggambarkan kondisi yang sebenarnya di lapangan. Teknik pengumpulan data yang digunakan adalah wawancara dan observasi (Moleong, 2007). Pemilihan informan dilakukan dengan Purposive sampling dan snowball sampling. Pada awalnya peneliti akan mendatangi pihak kelurahan untuk mengetahui informan kunci terkait penelitian. Dari informan kunci, maka nanti akan dapat ditentukan informan-informan yang terkait dengan penelitian.

Data yang didapatkan baik dari hasil wawancara maupun observasi akan diperiksa keabsahannya dengan metode trianggulasi data (Moleong, 2007). Dalam pemerikasaan data ini peneliti akan menempuh dengan langkah : 1)
Membandingkan data hasil pengamatan dengan data hasil wawancara, 2) Membandingkan data yang akan dikatakan orang didepan umum dengan data yang dikatakan secra pribadi, 3) Membandingkan hasil wawancara dengan isi suatu dokumen yang berkaitan. Teknik analisa data yang digunakan adalah menelaah seluruh data, reduksi data, menyusun dalam satuan satuan, mengategorisasi, pemeriksaan keabsahan data dan penafsiran data (Moleong, 2007).

\section{Hasil dan Diskusi}

\section{A. Profil Desa Banyuanyar}

Banyuanyar merupakan salah satu desa yang merupakan bagian dari Kecamatan Ampel. Secara adminitratif memiliki 9 kawasan dukuh yang terbagi menjadi 4 wilayah dusun dengan jumlah penduduk mencapai 2495 orang (laki-laki sejumlah 1244 dan perempuan sejumlah 1251).

Dari sisi geografis, daerah di Banyuanyar masuk ke dalam daerah dataran tinggi dengan tingkat kemiringan $2-15 \%$ dan ketinggian \pm . 420 meter diatas permukaan laut. Curah hujan di Desa Banyuanyar sejumlah $17,33 \mathrm{~mm} /$ tahun dengan jumlah bulan kering 7 bulan dalam satu tahun.

Desa Banyuanyar secara umum memliki karakteristik lingkungan berupa dataran Tinggi dengan sebagian besar berupa lingkungan/tanah kering. Karakter lingkungan wilayah ini mempengaruhi jenis usaha pertanian tanaman pangan, dengan pengembangan pada lingkungan. Kondisi lingkungan di Desa Banyuanyar yang terdiri dari tanah kering ini cocok untuk pengembangan pertanian tanaman pangan lahan kering, khususnya palawija, dan tanaman holkikutura, peternakan, perkebunan serta untuk pengembangan industri kecil sampai Industri besar yang ramah lingkungan. 
B. Analisis Potensi di Desa Banyuanyar

1. Agrowisata Tanaman Kopi

Kopi merupakan jenis minuman yang sudah lama dikonsumsi oleh masyarakat Indonesia. Gaya hidup minum kopi pun saat ini sedang trend terutama di kalangan milenial. Minum kopi dapat dikatakan sebagai salah satu gaya hidup pada masa sekarang. Popularitas kopi meningkat dan ditambah dengan banyak bermunculannya coffee shop dan banyaknya varian kopi tentu semakin meningkatkan popularitas minum kopi. Gaya hidup minum kopi untuk bersosialisasi, bersantai atau sekedar gengsi atau prestise (Suisa dan Febrilia, 2014).

Di Desa Banyuanyar terdapat tanaman kopi yang merupakan kopi asli dari daerah tersebut. Kopi nangka merupakan jenis tanaman kopi yang asli, tumbuh dan berasal dari Desa Banyuanyar. Aroma khas nangka akan menyeruak begitu kopi disajikan. Kopi nangka memiliki tekstur bubuk kopi yang halus sehingga menghasilkan ampas kopi yang sedikit namun memilk kepekatan yang tinggi. Keunggulan lain dari kopi ini adalah masa produksi kopi lebih pendek jika dibandingkan jenis kopi lainnya.

Tanaman kopi jenis nangka ini pun banyak dijumpai di halaman depan rumah warga. Tanaman kopi pun dapat dengan mudah kita temukan di Desa Banyuanyar. Setiap petani minimal memiliki satu pohon kopi. Ketersediaan bahan baku pembuatan $\begin{array}{llr}\text { minuman } & \text { kopi } & \text { tentu } \\ \text { merupakan } & \text { sebuah } & \text { nilai }\end{array}$ tambah tersendiri untuk dijadikan sebuah daerah tujuan wisata.

Sebagai sebuah atraksi wisata, wisatawan dapat melihat sendiri bagaimana proses pembuatan minuman kopi. Dari kopi masih di pohon, kemudian dipetik biji kopinya. Para wisatawan tentu dapat mmeiliki kesempatan untuk mencoba memetik kopi langsung dari pohonnya. Biji kopi yang telah dipetik kemudian diolah menjadi bubuk kopi dan untuk disajikan sebagai minuman kopi. Para wisatawan dapat mengamati langsung dan mencoba membuat minuman kopi sendiri. Keberadaan coffee shop tentu menjadi nilai tambah karena wisatawan dapat langsung menyicip kopi yang telah diproduksi dari tempat aslinya. Wisatawan juga dapat membeli kopi bubuk untuk dijadikan sebagai oleholeh.

Hal ini juga akan memberikan implikasi kepada peningkatan ekonomi masyarakat. Tanaman kopi yang awalnya oleh masyarakat kurang diberdayakan secara optimal dan hanya dijual biji kopi kering yang harga di pasaran tidak terlalu tinggi tentu kini dapat dioptimalkan. Tanaman kopi kini telah diolah dan tersedia dalam bentuk bubuk kopi atau kopi siap minum dan tentu akan memberikan manfaat ekonomi yang lebih.

Di Desa Banyuanyar setidaknya terdapat 3 (tiga) varian jenis kopi. Selain kopi 
nangka juga terdapat jenis kopi Jawa dan kopi Robusta. Pengolahan biji kopi menjadi produk kopi saji awalnya diinisasi oleh KTT (Kelompok Tani Ternak) Ngudi Utomo. Dengan tujuan mampu meningkatkan harga jual minuman kopi KTT melakukan upaya agar masyarakat desa mendapat pelatihan pengolahan kopi.

\section{Produk Olahan Sapi}

Kabupaten Boyolali merupakan kabupaten yang terkenal sebagai kota sapi dan kota susu. Hal ini dikarenakan jumlah sapi perah mencapai 61.887 ekor dan termasuk kabupaten dengan populasi sapi ternak tertinggi di Provinsi Jawa Tengah (Premisti, dkk : 2016).

Desa Banyuanyar pun
memiliki peternakan sapi
perah. Sapi perah berada di
bawah binaan KTT (Kelompok
Tani Ternak) Sido Makmur.
Bekerja sama dengan BPTP
(Badan Pengkajian Teknologi
Pangan) Semarang dan Dinas
Peternakan. Peternak sapi di
Desa Banyuanyar dapat
menghasilkan kurang lebih 150
liter susu sapi dalam setiap
pemerahan susu sapi. Proses
pemerahan susu sapi biasanya
dilakukan selama dua kali
dalam sehari. Pagi hari pada
jam 06.00 s/d 08.00 wib dan
pada sore sebelum ashar.
Memanfaatkan peternakan
sapi perah yang berada di Desa
Banyuanyar, dapat
dioptimalkan untuk menjadi
sebuah daya tarik wisata.
Wisata edukasi atau wisata
berbasis peternakan dapat
diterapkan disini. Masyarakat

pun juga dapat menjual susu segar yang dapat langsung dinikmati oleh wisatawan.

Produk olahan sapi perah pun mampu meningkatkan daya tarik wisata di kawasan ini. Proses mulai dari memerah susu sapi sampai pembuatan produk olahan susu serta wisata belanja produk olahan susu tentu selain menarik minat wisatawan untuk datang juga mampu meningkatkan perekonomian masyarakat. Produk olahan sapi perah yang selama ini telah dihasilkan oleh Desa Banyuanyar adalah Yoghurt asli, es lilin yoghurt dan Es Krim yoghurt.

3. Potensi Penunjang Lainnya

Di Desa Banyuanyar
potensi utama yang dapat
dijadikan sebagai atraksi
wisata adalah kopi dikarenakan
semua KTT (Kelompok Tani
dan Ternak) hampir semuanya
memiliki tanaman kopi, tetapi
yang fokus dalam pengelolaan
untuk dijadikan sebuah produk
hanya KTT Ngudi Utomo
(Kelompok Tani dan Ternak)
dan KTT (Kelompok Tani dan
Ternak) Sido Makmur yang
fokus pada perkebunan.

Potensi wisata yang dapat dijadikan sebagai penunjang adalah tanaman multikultural. Seperti KTT (Kelompok Tani dan Ternak) Sumber Widodo I di Dusun Wangan, Desa Banyuanyar yang tidak memiliki produk unggulan serta pengelolaan akan tetapi kegiatan nya khusus di pertanian pada temulawak. Temulawak merupakan termasuk dalam tumbuhan rimpang yang memiliki banyak 
khasiat untuk obatan, minuman, bahan pewarna alami, atau dijadikan sebagai bahan olahan seperti tepung, pati, minuman instan, manisan, kue, dodol, permen, dan cake (Khamidah, dkk : 2017).

\section{Jumlah}

tanaman

temulawak di Desa

Banyuanyar cukup besar dan melimpah akan tetapi dari sisi SDM masi terkendala untuk membuat varian produk yang layak jual dan pemasarannya. Hal ini jika dikombinasikan dengan pariwisata tentu akan menjadi solusi bagi masyarakat untuk memanfaatkan tanaman temulawak dengan optimal.

Sebagai atraksi penunjang terdapat juga Sendhang Mandhirejo yang merupakan salah satu sumber air di Desa Banyuanyar. Potensi penunjang lainnya adalah keberadaan kuliner khas yaitu "pecel gendar". Gendar pecel merupakan salah satu makanan yang menyajikan aneka sayuran yang dibaluri sambel kacang dan sebagai pengganti nasi adalah gendar (variasi olahan nasi).

Kesenian yang dimiliki oleh Desa Banyuanyar adalah karawitan dan Drumblek. Seni karawitan bahkan menjadi mata pelajaran untuk sekolah dasar yang terletak di Desa Banyuanyar. Kesenian "Drumblek" cukup terkenal di Kecamatan Ampel. Hampir mirip dengan konsep marching band hanya saja instrumen yang digunakan berbeda. Instrumen dalam drumblek biasanya menggunakan bekas direjen, ember, kaleng bekas dan bambu. Memanfaatkan barang-barang yang sudah tidak bisa dipakai dan dikemas dalam aransemen musik, kesenian drumblek cukup menyenangkan untuk dinikmati.
C. Komunitas masyarakat pada desa wisata

Kunci sukses dalam kegiatan kepariwisataan adalah memiliki sebuah komunitas yang mampu menerima wisatawan dan memiliki komitmen yang tinggi dalam pengelolaan pariwisata. Kegiatan kepariwisataan sangat terkait antara hubungan host (tuan rumah) dan guest (tamu). Hal ini tentunya membutuhkan sebuah komunitas yang solid yang mampu berinteraksi dengan wisatawan.

Di dalam pariwisata berbasis masyarakat dimana kekuatan utama berada pada masyarakat (komunitas) sehingga perlu disiapkan masyarakat yang memiliki kesadaran wisata. Kondisi faktual di Desa Banyuanyar sendiri pada saat ini, komunitas yang memiliki potensi adalah kelompok pengerak kopi atau KTT Ngudi Utomo. Hal ini dikarenakan kelompok ini sudah terbiasa mengelola guest (tamu) yang datang dengan motivasi untuk belajar tentang kopi nangka atau sekedar datang untuk menyicipi kopi nangka.

Di Desa Banyuanyar juga terdapat organisasi karang taruna yang merupakan organisasi sosial kepemudaan. Keberadaan karang taruna dapat membantu pengembangan desa wisata di Desa Banyuanyar. Pada sebuah desa wisata kehadiran sebuah kelompok sadar wisata (pokdarwis) tentu sangat diperlukan. Akan tetapi kendala yang dihadapi oleh Desa Banyuanyar belum memiliki POKDARWIS dikarenakan masih panjang jalan yang harus dilalui untuk menjadi desa wisata. Untuk saat ini Desa Banyuanyar akan fokus untuk memperkuat komunitas yang dimiliki untuk mempersiapkan diri menjadi desa wisata.

\section{Potensi SDM Lokal yang Mendukung}

Pengembangan pariwisata berbasis masyarakat diharapkan mampu untuk meningkatkan dan memberdayakan potensi SDM pada suatu desa. Hal ini dimaksudkan agar masyarakat mampu 
meningkatkan kapasitas dan produktivitas secara ekonomi bagi SDM pada sebuah desa. Memberdayakan SDM lokal juga diharapkan akan mengurangi tingkat urbanisasi sehingga penduduk dengan usia produktif bisa berkembang dan berdaya di desa dan saling memberikan manfaat satu sama lain.

Dari sisi potensi SDM, Desa Banyuanyar memiliki cukup banyak potensi SDM. Di desa tersebut terdapat organisasi pemuda karang taruna yang berisi anak muda usia produktif dari usia SMP sampai 30 tahunan. Terdapat juga SDM dari ibu-ibu PKK dan darma wanita yang mampu menjadi sentral dari pemberdayaan masyarakat melalui kegiatan wisata.

Karang taruna juga merupakan organisasi yang fokus dengan peningkatan dan pengembangan kompetensi SDM nya. Di Karang taruna tiap anggota karang taruna diharapkan dapat mengembangkan ide inovatif mereka demi kemajuan desa.

Desa Banyuanyar sendiri dicanangkan menjadi desa green smart village. Program ini bertujuan untuk meningkatkan kualitas masyarakat dalam hal IT (teknologi informasi). Keunggulan yang dimiliki dari sisi IT ini merupakan sebuah keunggulan tersendiri dan diharapkan dapat membawa kebaikan untuk masyarakat Desa Banyuanyar.

\section{E. Potensi dan Dukungan Ketersediaan Fasilitas dan Sarana Prasarana Dasar}

Aktivitas kegiatan pariwisata berbasis masyarakat akan berjalan baik dan lancar jika memiliki fasilitas dan sarana prasarana yang memadai. Pada saat ini fasilitas yang dimiliki oleh Desa Banyuanyar adalah workshop pembuatan kopi dan sekaligus coffee shop untuk berjualan kopi. Selain kopi nangka, juga dipasarkan adalah kopi robusta dan kopi jawa. Akan tetapi yang menjadi produk unggulan dan produk andalan adalah kopi nangka. Keadaan workshop sendiri dapat dikatakan sudah cukup layak untuk menerima wisatawan.

Fasilitas lainnya yang sudah tersedia adalah hotspot atau wifi yang sudah tersedia di desa dan dengan ketersediaan
21 titik wifi hotspot yang tersebar di Desa Banyuanyar. Keberadaan internet gratis ini tentu akan menjadi nilai tambah bagi wisatawan yang akan berkunjung ke Desa banyuanyar. Dalam hal ketersediaan akomodasi memang belum ada akan tetapi sudah direncanakan beberapa rumah penduduk yang potensial untuk dapat dijadikan homestay.

Dari sisi aksesibilitas Desa Banyuanyar dapat dikatakan strategis, hanya berjarak kurang lebih $10 \mathrm{~km}$ dari pusat Kota Boyolali. $18 \mathrm{~km}$ dari Kota Salatiga, serta berjarak $45 \mathrm{~km}$ dari Kota Surakarta. Posisi Desa Banyuanyar sendiri terletak pada jalur utama Solo - Semarang dan dekat dengan jalan besar. Untuk menuju Desa Banyuanyar pun dapat dengan moda transportasi pesawat, kereta, bus atau mobil. Kondisi jalan di Desa Banyuanyar sudah beraspal dan dapat dilalui oleh mobil.

Fasilitas dan sarana penunjang yang mendukung wisatawan dan sudah existing adalah tempat ibadah (masjid) untuk umat muslim, gereja dan wihara. Terdapat puskesmas sebagai fasilitas kesehatan. Fasilitas penunjang lainnya adalah perpustakaan, coffee shop, peternakan sapi, lapangan, warung dan taman.

\section{F. Potensi dan Kemampuan dalam Menciptakan Pasar Wisatawan}

Dalam industri kepariwisataan, ketersediaan pasar memegang peranan penting untuk keberlangsungan sebuah destinasi. Menciptakan pasar wisatawan merupakan sebuah cara untuk mendukung pengembangan pariwisata berbasis masyarakat. Proses yang harus dilalui untuk menciptakan pasar wisatawan adalah membangun networking dengan stakeholder di bidang pariwisata. Membangun kerjasama dengan mitra, mengembangkan media promosi, dan melakukan promosi dan pemasaran pariwisata kepada wisatawan secara langsung.

Kelemahan terbesar yang dimiliki Desa Banyuanyar selama ini adalah pada kemampuan menciptakan pasar. Hal ini juga terjadi pada produk-produk yang sudah existing. Perlu dilakukan pelatihan 
dan pembinaan dalam hal marketing terutama untuk mengatur produk yang menarik dan bagaimana pemasarannya.

\section{Kesimpulan}

Desa Banyuanyar secara umum memiliki potensi untuk dapat dikembangkan sebagai desa wisata yang merupakan sebuah bentuk pengembangan pariwisata berbasis masyarakat. Berdasarkan kriteria pengembangan desa wisata, Desa Banyuanyar memiliki keunggulan pada aspek potensi, fasilitas dan sarana parasarana, SDM, serta Komunitas. Kelemahan yang masih dimiliki oleh Desa Banyuanyar adalah pada aspek pemasaran. Aspek pemasaran ini merupakan penyakit yang sering dijumpai pada desa wisata. Hal yang dapat dilakukan untuk masalah pemasaran adalah dengan melakukan pembelajaran dan pelatihan terkait marketing terutama di era marketing 4.0. Melibatkan anak muda juga akan menjadi nilai tambah karena anak muda biasanya lebih memahami karakteristik pasar dan trend yang saat ini sedang berlangsung. Mewujudkan desa wisata yang merupakan perwujudan dari pengembangan masyarakat melalui kegiatan wisata membutuhkan peran serta dan kerjasama dari beberapa pihak yang terlibat. Sebuah desa wisata tidak akan berjalan jika hanya satu pihak atau satu orang yang bekerja, tetapi membutuhkan kolaborasi dan satu suara dari berbagai pihak. Desa wisata bukanlah sesuatu yang akan cepat memberikan keuntungan tapi jika dikelola dengan rajin dan tekun akan memberikan manfaat yang baik untuk sebuah desa dapat berkembang.

\section{References}

[1] Anwas, O.M. 2013. Pemberdayaan Masyarakat di Era Global.Alfabeta. Bandung.

[2] Astuti, L.I, Hermawan, Rozikin, M. 2015. Pemberdayaan Masyarakat Dalam Pembangunan Pertanian Berkelanjutan. Jurnal Administrasi Publik JAP, Vol. 3, No. 11, hal.1886-1892.
[3] Brohman, J. 1996. New Directions for tourism in the thirld world. Annals of tourism research vol. 23 , no 1 , hal 48-70.

[4] Demartoto, A. 2009. Pembangunan Pariwisata Berbasis Masyarakat. Sebelas Maret University Press. Surakarta.

[5] Hadiwioyo, S.S. 2012. Perencanaan pariwisata pedesaan berbasis masyarakat (sebuah pendekatan konsep). Yogyakarta : Graha Ilmu

[6] Direktorat Pemberdayaan Masyarakat. 2013. Buku Panduan Kriteria Pengembangan Desa Wisata. Kementerian Pariwisata dan Ekonomi Kreatif. Jakarta.

[7] Khamidah, A. Antarlina, S.S. Sudaryono, T. 2017. Ragam Produk Olahan Temulawak untuk Mendukung Keanekaragaman Pangan. Jurnal Litbang Pertanian Vol. 36, No. 1, Hal. 1 - 12.

[8] Moleong, L.J. 2007. Metodologi Penelitian Kualitatif (edisi revisi). Rosda Karya. Bandung.

[9] Nuryanti, W. 2015. The Power Of Culture In Sustainable Development. International Conference Culture in the Post-2015 Sustainable Development Agenda. May, 15, 2015. Hangzhou - RRC.

[10] Pitana, G.I, Gayatri, P.G. 2005. Sosiologi Pariwisata. Andi. Yogyakarta.

[11] Premisti, P.U.L., Setiadi, A. Sumekar, W. 2016. Pemasaran Susu di Kecamatan Mojosongo dan Kecamatan Cepogo, Kabupaten Boyolali. Jurnal Mediagro Vol. 12, No. 1, Hal. 27-34.

[12] Rogi, C.H. 2015. Dinamika Pengembangan Desa WIsata Brayut di Kabupaten Sleman. Skripsi. Universitas Gadjah Mada. Yogyakarta.

[13] Suisa, K., Febrilia, V. 2014. Gaya Hidup Minum Kopi di The Coffee Bean \& Tea Leaf Plasa Tunjungan Surabaya. Jurnal Hospitality dan Manajemen Jasa Vol 2, No 2. Hal. $326-343$.

[14] Yoeti, O.A. 2008. Perencanaan dan Pengembangan Pariwisata. Pradnya Paramita. Jakarta.

[15] Wrihatnolo, R.R, Nugroho, D.R, 2007. Manajemen pemberdayaan : Sebuah Pengantar dan panduan untuk Pemberdayaan Masyarakat. PT Elex Media Komputindo. Jakarta. 